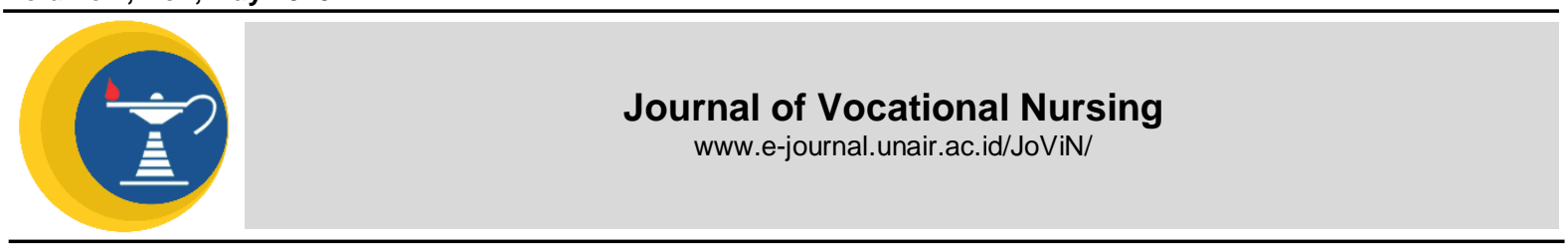

\title{
RELATIONSHIP OF FOOD CONSUMPTION PATTERNS WITH INCREASING BLOOD PRESSURE IN ADULTS
}

Susilo Harianto

DIII Nursing Study Program, Departement of Health, Faculty of Vocational Studies, Universitas Airlangga

\section{A B STRACT}

Introduction: A healthy diet is a way or effort in regulating the number and type of food with certain intentions such as maintaining health, nutritional status, preventing or helping to cure disease. Blood pressure is the power caused by the heart that contracts like a pump, so that blood continues to flow in the blood vessels. A person's blood pressure can be more or less than the normal value limit. The trigger factor for changes in blood pressure is one of them about food consumption patterns, such as consuming excess salt.

Methods: The purpose of this study was to determine the relationship of food consumption patterns with increased blood pressure. The design of this study uses analytics using the Case Control and sampling approach that is used is a non probability sampling with a number of 60 people and the number of samples taken by 36 respondents. Data collection used questionnaires coded, scored, tabulated and analyzed using the ChiSquare test.

Results: The results of the study were 20 respondents (56\%) with dietary patterns that did not fit the diet, 20 respondents (56\%) with high blood pressure, from the Chi-Square analysis of 0,000 showed a significant value, meaning $\mathrm{HO}$ was rejected or there was a relationship between consumption patterns food with increased blood pressure.

Conclusion: Based on the results of the study, it can be concluded that there is a relationship between food consumption patterns and an increase in blood pressure.
ARTICLE INFO

Recived 27 December 2019

Accepted 11 May 2020

Online 29 May 2020

*Correspondence:

Susilo Harianto

*Email:

susilohariantokandar@gmail.com

\section{INTRODUCTION}

Hypertension is a complex blood pressure. This can happen because the heart works harder to meet the body's oxygen and nutritional needs. If left unchecked, this disease can release the function of other organs, especially vital organs such as the heart and kidneys (National Riskesdas, 2013).

WHO data (World Health Organization) around the world around 972 million people or $26.4 \%$ of the inhabitants of the earth suffer from hypertension, from 972 million people with hypertension, 333 million in developed countries and 639 on the left in developing countries, including Indonesia. Hypertension was also ranked 2 nd out of the 10 most diseases in outpatients in Indonesia in 2006 with a prevalence of $4.67 \%$ and in 2013 the prevalence of hypertension increased to $9.5 \%$.
The number of hypertensive sufferers throughout the world continues to increase. In Asia, 38.4 million people with hypertension were announced in 2000 and predicted to be 67.4 million by 2025 . In Indonesia, it reaches $17-21 \%$ of the population and is not taken into account (Muhammadun, 2010).

At present Indonesia is in the phase of an epidemiological transition which results in a shift in the pattern of diseases from infections to non-communicable diseases (Stefhany, 2012).

Whereas for most cases of inpatient disease, for government type A general hospitals, hypertension was in the second position as many as 12,590 cases and in general government hospitals type C hypertension was in second place with 7,355 cases (East Java Health Office, 2013). 
Some risk factors are included in factors that cannot be controlled such as genetics, age, sex, and race. While risk factors that can be controlled in the form of behavior or lifestyle such as obesity, lack of activity, stress and food consumption (Rawasiah, 2014).

Hypertension or better known as high blood pressure disease is a condition where a person is declared to have increased blood pressure above the normal limit. A person is diagnosed with hypertension if the systolic pressure reaches above $140 \mathrm{mmHg}$ and diastolic pressure is above $90 \mathrm{mmHg}$ (Junaidi, 2010)

Some studies that have factors related to hypertension indicate a significant relationship between fruit and vegetable consumption and the incidence of hypertension (Susanto, 2010).

The wrong diet is one of the risk factors that increase hypertension. Modern food factors as a major contributor to the occurrence of hypertension (US, 2010).

There is a correlation between increasing consumption of vegetables and fruit, with a decrease in food fat consumption, accompanied by a decrease in consumption of total fat and saturated fat, which can reduce blood pressure (Aisyiyah, 2009).
Diet will affect health, especially blood vessels and the heart, people's habits of consuming higher cholesterol food, culture of eating society with delicious dishes, often consuming beef in the form of rendang, high saturated fat and dietary patterns that have the potential for hypertension in the form of eating habits contrary to nutrition programs, for example vegetables are rarely found in the menu (Herwati, 2013).

\section{MATERIALS AND METHODS}

The design in this study was Case Control analytic, which was a study that compared between case groups and control groups to find out the proportion of events based on history of exposure or absence. The design of this study is known as a retrospective nature, that is, the design by looking back from an event

that is related to the incidence of pain studied. The population in this study were all adults in the Mud Village of Gresik

District, Gresik Regency. Using purposive sampling method in this study there were 36 respondents with hypertension totaling 20 people and not hypertension 16 people. Data collection in this study uses questionnaires.

\section{RESULTS}

Table 1 Distribution of Respondents by Age

\begin{tabular}{|c|c|c|c|}
\hline No & Age & Frequency & Percentage \\
\hline 1 & $35-39$ & 14 & 38 \\
\hline 2 & $40-49$ & 11 & 31 \\
\hline 3 & $>50$ & 11 & 31 \\
\hline \multicolumn{2}{|c|}{ Total } & 36 & 100 \\
\hline
\end{tabular}

Shows that almost half of the respondents have $35-39$ years (38\%) and the rest have 40 years to more than 50 years.

Table 2 Distribution of Respondents Based on Latest Education

\begin{tabular}{cccc}
\hline No & Education & Frequency & Percentage \\
\hline 1 & No School & $\mathbf{0}$ & $\mathbf{0}$ \\
2 & Grammar school & 9 & 25 \\
3 & Elementary school & 12 & 33 \\
4 & Junior High School & 14 & 39 \\
5 & Academic/ College & 1 & 3 \\
\hline
\end{tabular}

Shows that almost half of the respondents had high school / equivalent education (39\%) and none of them did not attend school. 
Table 3 Distribution of Respondents by work

\begin{tabular}{cccc}
\hline No & Job & Frequency & Percentage \\
\hline 1 & Housewife & 21 & 58 \\
2 & Farmer & 0 & 0 \\
3 & Entrepreneur & 6 & 17 \\
4 & PNS & 0 & 0 \\
5 & Private & 9 & 25 \\
\hline
\end{tabular}

Shows that most work as housewives (58\%) and none of them work as farmers or civil servants.

Table 4 Distribution of Respondents Based on Food Consumption Patterns

\begin{tabular}{|c|c|c|c|}
\hline No & $\begin{array}{c}\text { Food Consumption } \\
\text { Patterns }\end{array}$ & Frequency & Percentage \\
\hline 1 & Fit & 16 & 44 \\
\hline 2 & Not Fit & 20 & 56 \\
\hline \multicolumn{2}{|c|}{ Total } & 36 & 100 \\
\hline
\end{tabular}

Shows that most respondents had an inappropriate diet (56\%).

Table 5 Distribution of Respondents Based on Blood Pressure

\begin{tabular}{|c|c|c|c|}
\hline No & Blood Pressure & Frequency & Percentage \\
\hline 1 & Low & 0 & 0 \\
\hline 2 & Normal & 16 & 44 \\
\hline 3 & High & 20 & 56 \\
\hline \multicolumn{2}{|c|}{ Total } & 36 & 100 \\
\hline
\end{tabular}

Shows that the majority of respondents had high blood pressure (56\%) and none had low blood pressure.

Table 8 Cross Tabulation of Food Consumption Patterns with Blood Increase

\begin{tabular}{|c|c|c|c|c|c|}
\hline \multirow{2}{*}{ No } & \multirow{2}{*}{$\begin{array}{l}\text { Food Consumption } \\
\text { Patterns }\end{array}$} & \multicolumn{3}{|c|}{ Frequency } & \multirow{2}{*}{ Percentage } \\
\hline & & Low & Normal & High & \\
\hline 1 & Fit & 0 & 16 & 0 & 44 \\
\hline 2 & Not Fit & 0 & 0 & 20 & 56 \\
\hline \multicolumn{2}{|c|}{ Total } & 0 & 16 & 20 & 100 \\
\hline
\end{tabular}

Shows that of the 36 respondents, 20 respondents who had inappropriate food consumption patterns suffered from high blood pressure as many as 20 respondents (56\%) and respondents who patterned their food consumption accordingly had normal blood pressure of 16 respondents (44\%). Based on the results of data analysis to answer the research hypothesis with the Chi-Square test in SPSS with $\alpha=$ 0.05 the results $\rho=0.00$ are $\rho<\alpha$ which means that $\mathrm{H} 0$ is rejected and $\mathrm{H} 1$ is accepted which means there is a relationship between food consumption patterns and blood pressure increases in Mud Village of Gresik District, Gresik Regency.

\section{DISCUSSION}

Food Consumption Pattern, The results showed that most of the feed consumption patterns were not in accordance with the diet of 20 respondents (56\%) and almost half of the food consumption patterns were in accordance with the diet as many as 16 respondents (44\%). According to Ramadan (2008), a healthy diet is a way or effort in regulating the total and type of food with certain intentions such as maintaining health, nutritional status, preventing or helping cure illness. Daily diet is a person's diet that is related to eating habits every day. According to Arumi (2011), healthy foods for hypertensive patients are nuts, bananas, soybeans, avocados, dark chocolate. Whereas According to Ramadan (2008), foods that must be avoided by hypertensive patients are instant noodles, margarine, milk, pickles, french fries, smoked meat, sugar, and alcohol.

Diet is a way for someone who is associated with eating habits every day. The trigger factor for changes in blood pressure is the other factor about food consumption patterns. Foods with high salt content are generally found in processed foods, such as 
cheese, canned foods, salted fish, and sausages. Hypertension sufferers are more advised to consume natural foods, have not undergone a processing process, such as fresh vegetables, fresh fruit, cereals, nonfat milk, and lean meat. Most people in the village of Mud consume more of the sea fish than vegetables because most of the respondents' jobs are housewives whose families live as fishermen, this is not in accordance with the diet of people with hypertension so that it can trigger an increase in blood pressure .

Mellisa (2013) states that there is a relationship between exercise behavior, stress and diet with hypertension at Age.

The lack of consuming food sources containing potassium causes total sodium to accumulate and will increase the risk of hypertension (Junaedi et al. 2013).

Blood Pressure,The results showed that most of the food consumption patterns that did not fit the diet were 20 respondents (56\%) and almost half of their food consumption patterns were in accordance with the diet as many as 16 respondents (44\%).

According to Ramadan (2008), a healthy diet is a way or effort in regulating the total and type of food with certain purposes such as maintaining health, nutritional status, preventing or helping disease recurrence. Daily diet is a person's diet that is related to eating habits every day. According to Arumi (2011), healthy foods for people with hypertension are nuts, bananas. soybeans, avocado, thick chocolate. Meanwhile, according to Ramadan (2008), foods that should be avoided by hypertensive patients are instant noodles, margarine, milk, pickles, french fries, smoked meat, sugar, and alcohol.

Diet is a way of monitoring that relates to eating habits every day. The trigger factor for changes in blood pressure is one of them about food consumption patterns. Foods with high salt content are generally found in processed foods, such as cheese, canned foods, salted fish, and sausages. Hypertension sufferers are more advised to consume natural foods, have not undergone a processing process, such as fresh vegetables, fresh fruit, cereals, nonfat milk, and lean meat. Most people in the Mud Village of Gresik Subdistrict, Gresik District consume more sea fish than vegetables because most of the respondents' jobs are housewives whose family heads earn a living as fishermen. So that people consume marine fish more often than vegetables, this affects blood pressure.

Relationship of Food Consumption Patterns with Blood Pressure, The results showed that from 36 respondents, 20 respondents who had an inappropriate dietary pattern had 20 high blood pressure (56\%). and respondents who had a suitable food consumption had normal blood pressure as many as 16 respondents (44\%). The results of Chi-Square analysis show a value of $\rho \leq 0.05$, which is equal to 0,000 , between the variables of food consumption patterns with hypertension have a significant value, meaning that $\mathrm{HO}$ is rejected or there is a relationship between food consumption patterns with increased blood pressure.

Diet is a description of the type, total, and composition of food items that are eaten every day by one person who is a characteristic of a particular community group. Eating habits are the way individuals or groups choose, consume and use available food and are based on social and cultural factors where the individual or group lives. The main factor causing hypertension is closely related to the habit of consuming excess salt and is not balanced by increasing eating vegetables (Muhaimin, 2008).

Frilyan (2010) has a relationship between fruit and vegetable consumption in one day with hypertension, that respondents who consumed less fruit and vegetables, $(69.1 \%)$ were diagnosed with hypertension.

Adriaanz (2016) revealed that consumption of foods high in sodium can affect blood pressure rise.

The results of this study corroborate Nuarima's (2012) findings that consumption of fatty foods is not a risk factor for hypertension. American Diabetes Association (2016) says consumption of excess sweet foods not only adds weight but also increases the risk factors for type 2 diabetes.

Research conducted by Taslim, et al. (2016) on the relationship of diet and stress with the incidence of grade 1 and 2 hypertension in pregnant women in the working area of the Kamonji Health Center in West Palu Subdistrict "found results that there was a relationship between diet and stress with grade 1 hypertension events and 2.

In the community in the Mud Village of Gresik Subdistrict, Gresik District, the majority of the Mud community have eating habits that influence blood pressure, the majority of the Mudflow community live close to the sea so that they consume more marine fish more often. This is the main reason why the community blood pressure in the Mud Village of Gresik District, Gresik Regency tends to be high, because fish have a high fat content. Fat consumption is related to cholesterol levels in the blood. High cholesterol levels in the blood can cause thickening of the arteries. If there is more sediment, the walls of the blood vessels 
become stiffer or less flexible. This condition will aggravate the heart because the heart works harder when pumping blood so it aggravates hypertensive patients.

Ramayulis (2010) says that a wrong diet can cause an increase in blood pressure such as eating fatty foods, especially in the intake of saturated fat and cholesterol.

The research conducted by Mamoto et al. (2012) showed that there was a significant relationship between sodium intake and the incidence of hypertension.

Research conducted by Annisa (2009) shows that there is a relationship between potassium intake and hypertension. There was a significant relationship between physical activity, fat intake, and sodium intake with the incidence of hypertension (Mahmudah, 2015).

\section{CONCLUSION}

From the results of the research and discussion above, it can be concluded that the majority of respondents have good knowledge about the Elderly Posyandu. Based on the results of the study of the Relationship of Food Consumption Patterns with Increased Blood Pressure in Adults in the Mud Village of Gresik District, Gresik Regency. Can be concluded that:

1. Most adults in the Mud Village of Gresik Subdistrict, Gresik Regency have a food consumption pattern that is not in accordance with the diet.

2. Most adults in the Mud Village of Gresik District, Gresik District suffer from High Blood Pressure.

3. There is a strong correlation between food consumption patterns and increasing damh pressure in adults in the Mud Village of Gresik District, Gresik Regency.

\section{REFERENCES}

Adriaanz, Patricia N. dkk. 2016. Hubungan Konsumsi Makanan dengan Kejadian Hipertensi pada Lansia di Puskesmas Ranomuut Kota Manado. ejournal Keperawatan (e-Kp) Volume 4 Nomor 1, Mei 2016.

Aisyiyah, Farida Nur. 2009. Faktor Risiko Hipertensi pada Empat Kabupaten / Kota dengan Prevalensi Hipertensi Tertinggi Di Jawa dan Sumatera. Bogor : Departemen gizi masyarakat Fakultas Ekologi ManAge IPB.

American Heart Association.(2016) Hypertension. Medical Journal

Annisa .2009. Hubungan antara asupan natrium, kalium, kalsium dengan hipertensi di Puskesmas merbangsan
Yogyakarta : Universitas Gadjah Mada.

Arumi, S. (2011) Menstabilkan Darah Tinggi dan Darah Rendah. Paduan Hidup Sehat dengan Tekanan Darah Normal. Penerbit Araska Pinang Merah Residence Kav 14 Jl. Imogiri BaratBantul-Yogyakarta, pp.41-42.

AS, M. 2010. Hidup bersama hipertensi. Yogyakarta : In Book.

Dinas Kesehatan Provinsi Jawa Timur. 2013. Profil Kesehatan Provinsi Jawa Timur 2012. Surabaya: Dinas Kesehatan Jawa Timur.

Frylyan. 2010. Faktor-faktor yang Berhubungan dengan Hipertensi pada Age Lanjut di Tangerang. Kementrian Kesehatan Republik Indonesia 2007, Masalah Hipertensi di Indonesia, Dirjen Pengendalaian Penyakit dan Penyehatan Lingkungan.

Herwati dan Wiwi Sartika. 2013. Terkontrolnya Tekanan Darah Penderita Hipertensi Berdasarkan Pola Diet dan Kebiasaan Olahraga di Padang Tahun 2011. Jurnal Kesehatan Masyarakat, September2013-Maret 2014, Vol.8, No.1.

Junaedi E, Yulianti, S, Rinata, MG 2013, Hipertensi kandas berkat herbal, Fmedia (Imprint Agro Media Pustaka), diaskes 04 Maret 2018. https://books.google.co.id/books?id=JTIAwAAQBAJ\&printsec $=$ frontcover\&d $q=$ hipertensi\&hl=id\&sa $=X \& e i=K v H 2 V I$ HyMJGWuASDu4DwDg\&redir_esc=y\# $\mathrm{v}=$ onepage \& $\mathrm{q}=$ hipertensi\& $\mathrm{f}=\mathrm{false}$.

Junaidi, I. 2010. Hipertensi, Pengenalan, Pencegahan, dan Pengobatan. Jakarta: PT Bhuana IImu Populer.

Mahmudah, Solehatul, dkk. 2015. Hubungan Gaya Hidup dan Pola Makan dengan Kejadian Hipertensi Pada Lansia di Kelurahan Sawangan Baru Kota Depok Tahun 2015. Biomedika, Volume 7 Nomor 2, Agustus 2015.

Mamoto, F, Kandou, GC, Pijoh, VD 2012, Hubungan antara asupan natrium dan obesitas dengan kejadian hipertensi pada pasien poliklinik umum di puskesmas Tumaratas kecamatan Langowan Kabupaten Minahasa, hlm.1-6.

Mellisa. 2013. Hubungan antara perilaku olahraga, stress dan pola makan dengan tingkat hipertensi pada lanjut Age Di Posyandu Lansia Kelurahan Gebang Putih Kecamatan Sukolilo 
Kota Surabaya. Skripsi Tidak Dipublikasikan.

Muhaimin. (2008). Penyakit hipertensi. Diakses 14 September 2018, dari http://one.indoskripsi.comnode2197.m ht

Muhammadun, A. S. 2010. Hidup Bersama Hipertensi. Jogjakart: In-Books.

Nuarima, Agnesia. 2012. Faktor Resiko Hipertensi Pada Masyarakat di Desa Kabongan Kidul Kabupaten Rembang. Semarang : FK Undip.

Ramadhan, 2008. Seberapa Sehatkah Hidup Anda . Penerbit Think. Jogjakrta.

Ramayulis, R. 2010. Menu dan resep untuk penderita hipertensi. Jakarta : Penebar Plus+.

Rawasiah, A.B. (2014). Hubungan Faktor Konsumsi Makanan Dengan Kejadian Hipertensi Pada Lansia Di Puskesmas Pattinggalloang. Makassar.

Riset Kesehatan Dasar. 2013. Jakarta: Badan Penelitian danPengembangan Kesehatan, Departemen Kesehatan, Republik Indonesia.
Stefhany, Emerita. 2012. Hubungan Pola Makan, Gaya Hidup dan Indeks Massa Tubuh dengan Hipertensi pada Pra Lansia dan lansia di Posbindu Kelurahan Depok Jaya Tahun 2012. Skripsi, program Studi IImu Gizi, Fakultas kesehatan Masyarakat. Universitas Indonesia Depok.

Susanto. 2010. Cekal (Cegah dan Tangkal) Penyakit Modern. Yogyakarta : CV. Andi.

Taslim, R.W. Ramadani., Rina Kundre dan Gresty Masi. (2016). Hubungan Pola Makan dan Stres dengan kejadian Hipertensi Grade 1 dan 2 pada lbu Hamil di Wilayah kerja Puskesmas kamonji kecamatan Palu Barat. EJournal Keperawatan (ekp) Volume 4 Nomor 1, februari 2016.

WHO.(2010). World health statistics.(diakses tanggal 11 november 2018). http://www.who.int/entity/whosis/whost at/EN_WHS10_Full.pdf?ua=1. 